\title{
THE OCCURRENCE AND PATHOGENICITY OF PHOMA EXIGUA DESM. VAR. EXIGUA FOR SELECTED SPECIES OF HERBS
}

\author{
Zofia Machowicz-Stefaniak, Beata Zimowska, Ewa Zalewska
}

\begin{abstract}
Department of Plant Pathology, University of Life Sciences in Lublin, Leszczyńskiego 7, 20-069 Lublin, Poland e-mail: zofia.machowicz@up.lublin.pl, beata.zimowska@up.lublin.pl, ewa.zalewska@up.lublin.pl
\end{abstract}

Received: 12.09 .2007

S u m m a r y

$P$. exigua var. exigua was isolated from underground and aboveground organs of different herb plant species in the years 1998-2006. Pathogenicity tests of three randomly chosen isolates of the fungus T 299, T 261 and T 277 for thyme and of three isolates M 1657, M 1193 and M 1635 for lemon balm were carried out. The effect of water suspension of fungus spores on the germination ability of schizocarps and of infected soil on sprouting and seedling health was studied. The study of microscopic structures of the fungus developing on plants, isolation of the fungus on artificial media and macro- and microscopic analysis on standard media are essential for the correct identification of $P$. exigua var. exigua. The polyphagous nature of the fungus is confirmed by the obtained results. The tested isolates were found to be occasional pathogens of thyme and lemon balm in the studied conditions. The harmfulness of the tested isolates pointed to inhibition of schizocarp germination, sprouting of plants and the ability to cause necrosis of germs, roots and epicotyl.

Key words: P. exigua var. exigua, occurrence, pathogenicity, herbs

\section{INTRODUCTION}

Fungi of the genus Phoma occur commonly on different species of cultivated and wild plants (F a r r et al. 1995; B o e re ma et al. 2004). Considering the way of life and feeding, saprophytes, occasional parasites and specific pathogens of cultivated plants are distinguished among them (Marcinkow ska, 1985). Accidental parasites of some species of cultivated plants include, for example, the polyphagous species of $P$. exigua Desm. var. exigua. This fungus is distinguished from other varieties of this species by its ability to produce a colourless "E" metabolite in cultures. This metabolite enters into reaction with $1 \mathrm{~N}$ $\mathrm{NaOH}$, what is taken into account in the identification of these fungi (B o erema and Höweler, 1967; Marcinkowska, 1985).
Numerous isolates of $P$. exigua var. exigua have the ability to infect injured parts of plants from the genera of Cucumis, Glycine, Lupinus, Pisum and Raphanus (Marcinkowska, 1984). Only the isolate from the same plant species caused an inhibiting effect of $P$. exigua on the germination of achenes Celosia cristata and the growth of seedlings ( a c i c o w a et al. 1992). On the other hand, a decrease of the ability of Bellis perennis achenes to germinate was caused by $P$. exigua isolates independently of the origin. The fungus also caused necrosis of the roots of seedlings grown from artificially infected achenes ( $\mathrm{L}$ a c i c o w a et al. 1992). Apart from P. exigua var. foveata, P. exigua var. exigua belongs to the fungi causing the socalled gangrene of bulbs and the stem base of potato (B o e r e m a 1976). Numerous isolates of the fungus classified as the species $P$. exigua of $P$. exigua var. exigua were obtained as a result of the authors' own studies on herb diseases conducted since 1998.

As a result of frequent colonization of leaves, stems and roots of garden thyme and lemon balm by P. exigua var. exigua (M a ch ow i $\mathrm{z}-\mathrm{S}$ te fa n i a et al. 2002a; 2002b), pathogenicity tests were carried out on the isolates of P. exigua var. exigua as well as shizocarps and seedlings of thyme and lemon balm.

\section{MATERIALS AND METHODS}

The studies on fungi colonizing plants of different herb species cultivated in the Lublin region were conducted in the years 1998-2006 (Tab. 1). Fungi were identified on the basis of etiological symptoms occurring on plants, and they were isolated from superficially disinfected parts of plants, using the artificial culture method and a mineral medium (M a c h o w i c z - S t e faniak et al. 2002a; 2002b). One-spore cultures of fungi were identified on the maltose medium or on standard media. The successively obtained isolates of Phoma spp. were identified on the media of MA 
(maltose), OA (oats) and CA (cherry), based on the current principles of the taxonomy of fungi of the genus Phoma (de G r u y t e r and N o o r d e l o o s, 1992; de Gruyter et al. 2002).

Samples of the sowing material of thyme and lemon balm as well as 6 isolates of P. exigua var. exigua, randomly selected from the authors' individual collection of cultures of Phoma spp., were used in the pathogenicity tests. Isolates T 299, T 261 and T 277 were isolated from the thyme plants, while isolates M 1657, M 1193 and M 1635 were isolated from the lemon balm plants.

The pathogenicity tests examined the effect of $P$. exigua var. exigua on the germinating ability of shizocarps of thyme and lemon balm and the effect of the fungi through the infected soil on emergencies and health of the seedlings. The infection material consisted of conidia obtained from the one-spore cultures of the examined isolates, growing on the maltose medium (bioMérieux), at the temperature of $22^{\circ} \mathrm{C}$, without the access of light, in the form of a water suspension with the density of $3 \times 10^{5}$ conidia $\times \mathrm{ml}^{-1}$, with an addition of a few drops of Filpon preparation ( $\mathrm{Kac}$ i c ow a et al. 1992). The superficially disinfected shizocarps of thyme were soaked for 10 minutes in an infection suspension of the isolates T 299, T 261 and T 277, and those of lemon balm - in an infection suspension of the isolates M 1657, M 1193 and M 1635 (Machowicz-Stefaniak and Zimowska, 2000; Mar c in k ow s k a, 1984), after which 20 shizocarps were placed in each of the sterile moist chambers. 100 shizocarps, i.e. 5 dishes with 20 shizocarps in each, were used for each of the studied isolates and each plant species. The control was the shizocarps soaked for the same period in distilled water. The dishes with the plant material were kept in a thermostat at $30^{\circ} \mathrm{C}$ with full lighting during the day $(14 \mathrm{hrs})$ and at $20^{\circ} \mathrm{C}$ in darkness at night (10 hrs). Observations were conducted every three days, and after 9 days the number of shizocarps that had and had not germinated as well as the number of germs with necrosis were determined. The shizocarps that had not germinated and those that had germinated and whose germs had died out were submitted to reisolation according to Koch's postulates. Results obtained in the last observation were statistically analyzed using Tukey's confidence intervals.

The studies on the effect of $P$. exigua var. exigua on emergencies and health of seedlings considered single isolates of the fungus, i.e. T 299 and M 1657 , of high pathogenicity in laboratory tests. The infection material was prepared according to Noll ( $\mathrm{L}$ a c i c o w a , 1964), using compost earth with an addition of $5 \%$ ground rice as the culture subsoil. The superficially disinfected shizocarps of garden thyme and lemon balm were sown at points into Noll's mixture in pots with the diameter of $14 \mathrm{~cm}$, and they were covered with a $0.3 \mathrm{~cm}$ layer of earth. The control was the superficially disinfected shizocarps sown into the compost soil with an addition of ground rice. 50 shizocarps, 5 pots with 10 shizocarps in each, were used for the isolate of the fungus as well as the plant and the control. In total, the experiment considered 100 shizocarps of garden thyme and 100 shizocarps of lemon balm. The pots together with the shizocarps were kept for 35 days in a climatic chamber in the conditions of temperature, moisture and irradiation enabling the emergence and growth of plants. The number of the obtained plants was determined every 10 days, and after the experiment was finished, i.e. after 35 days, the occurrence of necrosis on the roots and the hypocotyl of plants was established. Next, the plant material was reisolated according to Koch's postulates. The results obtained in the last observation were submitted to statistical analysis using Tukey's confidence intervals.

\section{RESULTS}

The presence of P. exigua var. exigua was found on the underground and aboveground parts of the studied herb species. Pycnidia and spores typical of the genus Phoma were found on the surface of non-specific disease symptoms. The mycological analysis fully confirmed the occurrence of those fungi, including P. exigua var. exigua belonging to the section of Phyllostictoides. After 7 days the cultures of the studied isolates on the maltose medium produced an olive-brown, flocculent mycelium with a layered and slightly cutin edge and an olive-brown reverse. After 14 days the colour of the airy mycelium and the reverse was more intense. The structure of the colony was delicate, fluffy, concentrically zoned, with a layered and not very cutin edge. The diameter of the colony after 7 days was 25-38 $\mathrm{mm}$, and after 14 days 50-72 $\mathrm{mm}$. On the cherry medium, the colonies had a fluffy-flocculent or flocculent mycelium after 7 and 14 days. In the central part, the colonies were dark or brown-olive with a white edge. The reverse of the colony was olive-green. The diameter of the colony after 7 days was 30-42 $\mathrm{mm}$, and after 14 days $55-70 \mathrm{~mm}$. On the oat medium, the edge of the colony after 7 and 14 days was irregular, wavy or slightly layered. The structure of the mycelium was flocculent, brown or olive-brown with a light margin. The diameter of the colony after 7 days was $30-48 \mathrm{~mm}$, and after 14 days 50-75 $\mathrm{mm}$.

Pycnidia on the oat medium produced aggregates in the central part of the colony, with the structure similar to concentric rings. They were found on the surface of the agar in the airy mycelium or they were partly submerged in the agar. The pycnidia were spherical or almost spherical, dark brown or black, with one outlet and without a nodule (Figs 1a, b). Thick, creamy 
conidal exudate of the fungus flowed from the ostiole. The size of the pycnidia ranged from 74.2 to $185.5 \mu \mathrm{m}$. The conidia were differentiated in their shape and size, most frequently oval, elliptic or roundish, with singular drops of fat at each end, without any transverse divisions or - sporadically - with one dividing wall. The size of 0-division sporules was 3.7-7.4 x 2.5-3.7 $\mu \mathrm{m}$, and of those with one division 7.4-9.25 x 2.5-3.5 $\mu \mathrm{m}$ (photo 2). After $1 \mathrm{~N} \mathrm{NaOH}$ was sprinkled on the edge of the colony growing on MA medium, the medium became slightly green. The reaction with $\mathrm{NaOH}$ on the oat medium was negative. There were no crystals on the reverse of 14-day-old colonies.

The cultures of the examined fungus were isolated in the study years from 11 species of spice and medicinal plants cultivated in the region of Lublin (Tab. 1). Most frequently, they were obtained from superficially disinfected roots, stems and leaves of lemon balm and garden thyme as well as from stems and leaves of caraway and dill (Fig. 3). The fungus colonized the underground and aboveground parts of peppermint, parsnip, common motherwort, St. John's wort and garden sage. It was isolated not only from non-disinfected but also from superficially disinfected shizocarps of the majority of the studied species of herbaceous plants (Tab. 1).

In the experiment with inoculation of the water suspension of $P$. exigua var. exigua spor, from 71 to $76 \%$ of thyme shizocarps did not germinate till the $9^{\text {th }}$ day (Tab. 2). The mean number - ranging from 14.2 to 15.2 - of shizocarps that did not germinate was significantly higher than in the control combination (Tab. 3). On the other hand, no significant difference was found in the mean number of the shizocarps that did not germinate and that had contact with particular isolates of $P$. exigua var. exigua. Despite the contact with the studied isolates of the fungus, progressing necrosis of the germs was observed in the shizocarps that germinated. It occurred in the form of light brown spots graduating into streaks or it was present on the whole surface of the germs (Fig. 4). After 9 days, the percentage of the germs with necrosis ranged from 20 to 23 , and the mean number of the germs with necrosis ranged from 4.0 to 4.6 (Tab. 3). The latter values were significantly higher than the control value, while not differing from each other in a significant way (Tab. 3).

Table 1

Occurrence of Phoma exigua var. exigua on various herbs in the years $1998-2006$.

\begin{tabular}{|c|c|c|c|c|c|c|}
\hline \multirow{3}{*}{ Host plants } & \multicolumn{6}{|c|}{ Studied organs } \\
\hline & \multicolumn{2}{|c|}{ Shizocarps } & \multirow{2}{*}{ Roots } & \multirow{2}{*}{ Base of stem } & \multirow{2}{*}{ Stems } & \multirow{2}{*}{ Leaves } \\
\hline & a & $\mathrm{b}$ & & & & \\
\hline \multicolumn{7}{|l|}{ Lamiaceae } \\
\hline Thymus vulgaris L. & + & + & + & + & + & + \\
\hline Melissa officinalis L. & & + & +++ & ++ & + & + \\
\hline Mentha piperita $\mathrm{L}$. & & & + & + & + & + \\
\hline Leonurus cardiaca $\mathrm{L}$. & & & ++ & + & + & \\
\hline Salvia officinalis $\mathrm{L}$. & & & ++ & + & + & + \\
\hline \multicolumn{7}{|l|}{ Apiaceae } \\
\hline Carum carvi $\mathrm{L}$. & + & + & & + & ++ & + \\
\hline Anethum graveolens $\mathrm{L}$. & & ++ & & & +++ & + \\
\hline Pastinaca sativa $\mathrm{L}$. & & + & + & ++ & & \\
\hline Coriandrum sativum $\mathrm{L}$. & + & & & & & \\
\hline \multicolumn{7}{|l|}{ Asteraceae } \\
\hline Achillea millefolium L. & + & & & & & \\
\hline \multicolumn{7}{|l|}{ Hypericaceae } \\
\hline Hypericum perforatum $\mathrm{L}$. & & & ++ & + & + & + \\
\hline
\end{tabular}

a - undisinfected shizocarps

$\mathrm{b}-$ disinfected shizocarps

+- frequency up to $5 \%$

++ - frequency from $5 \%$ to $15 \%$

+++- frequency from $15 \%$ to $30 \%$ 


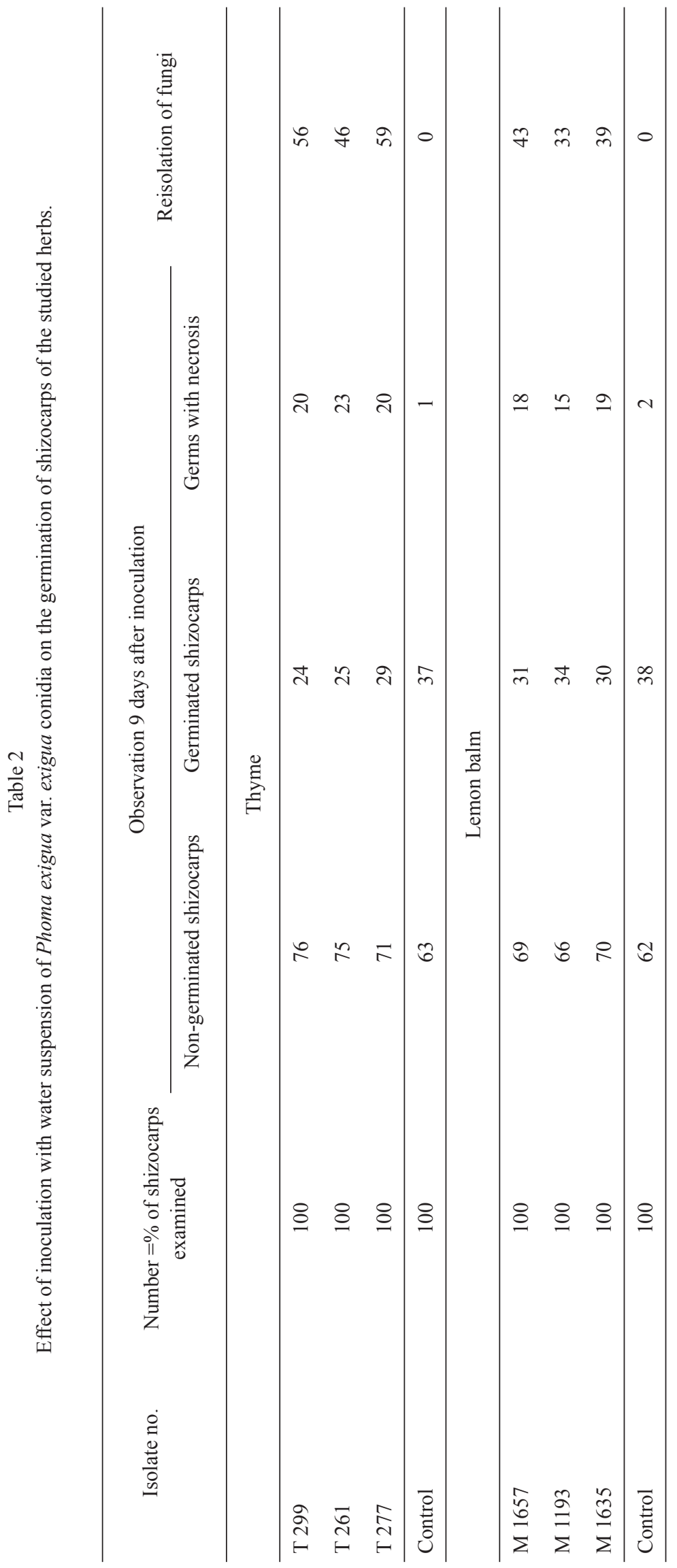




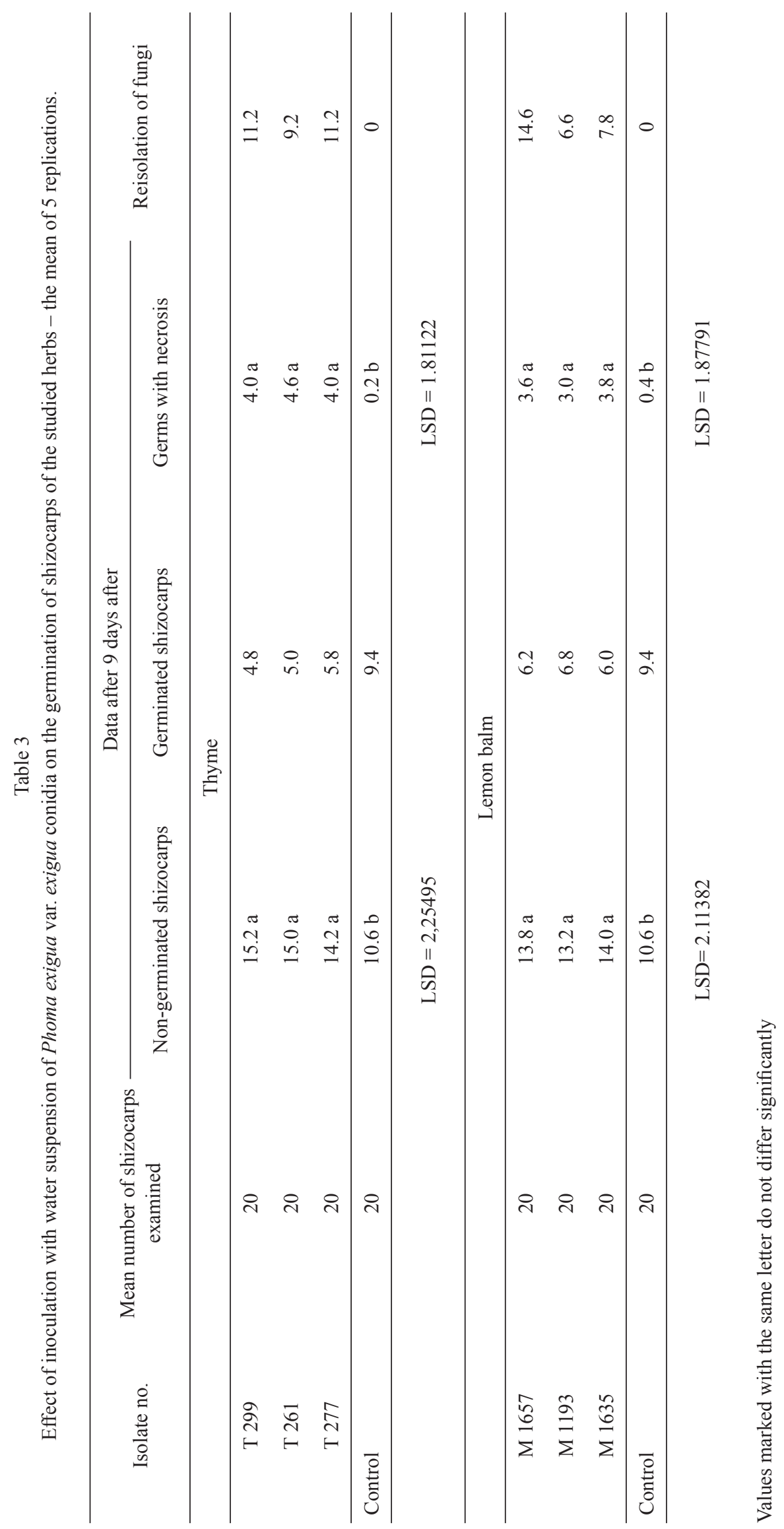




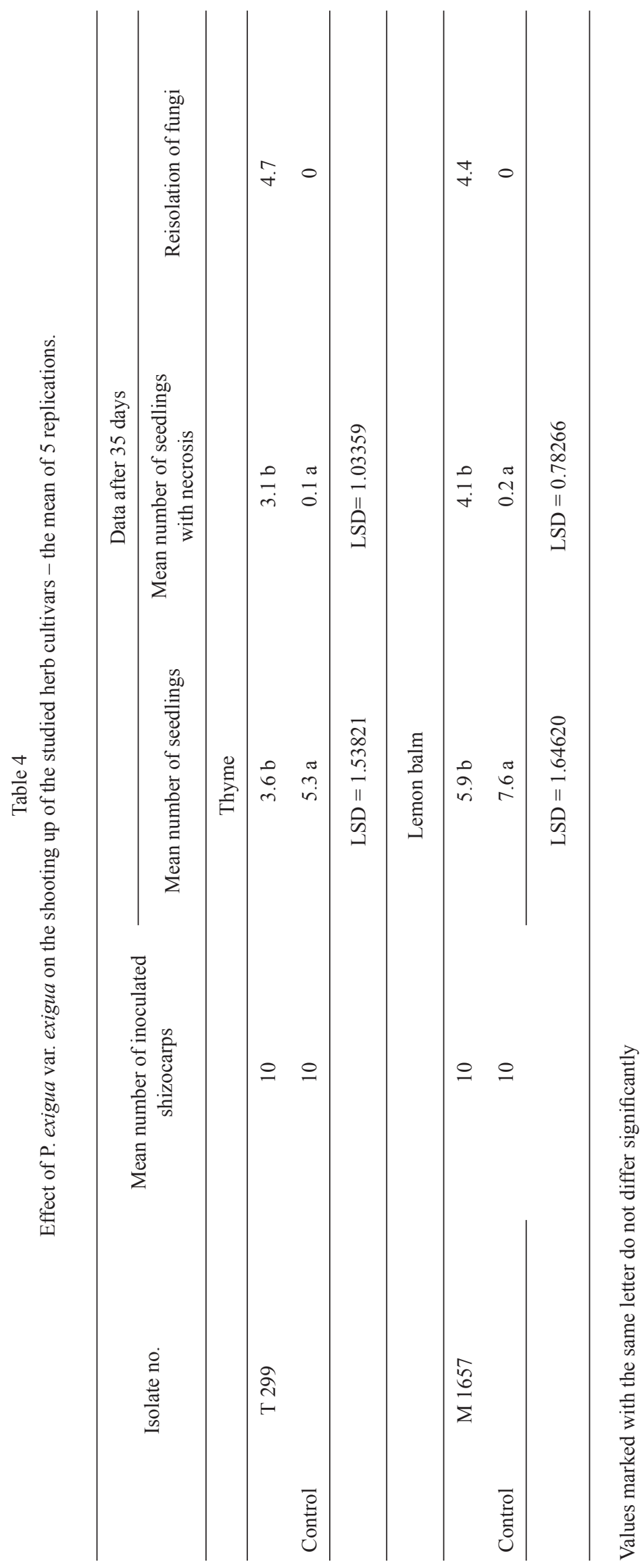



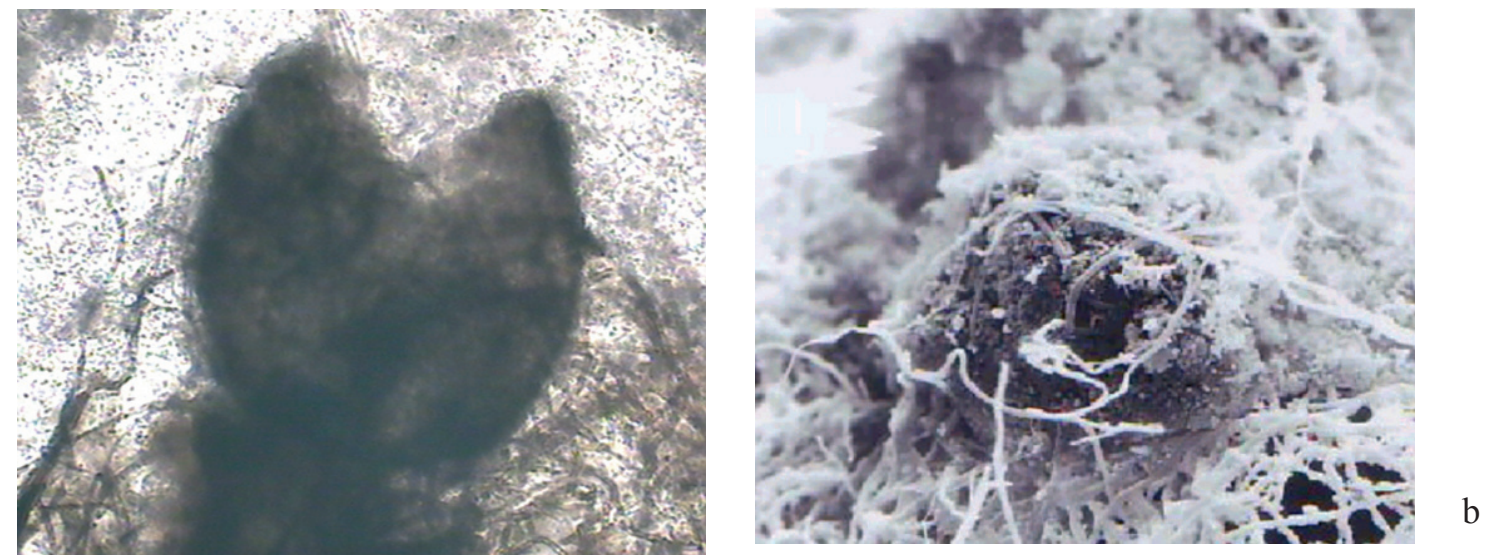

Fig. 1. Pycnidia of Phoma exigua var. exigua - x 125 (a) - photo E. Zalewska; SEM - x 450 (b) - photo M. Wróbel; on malt - agar.
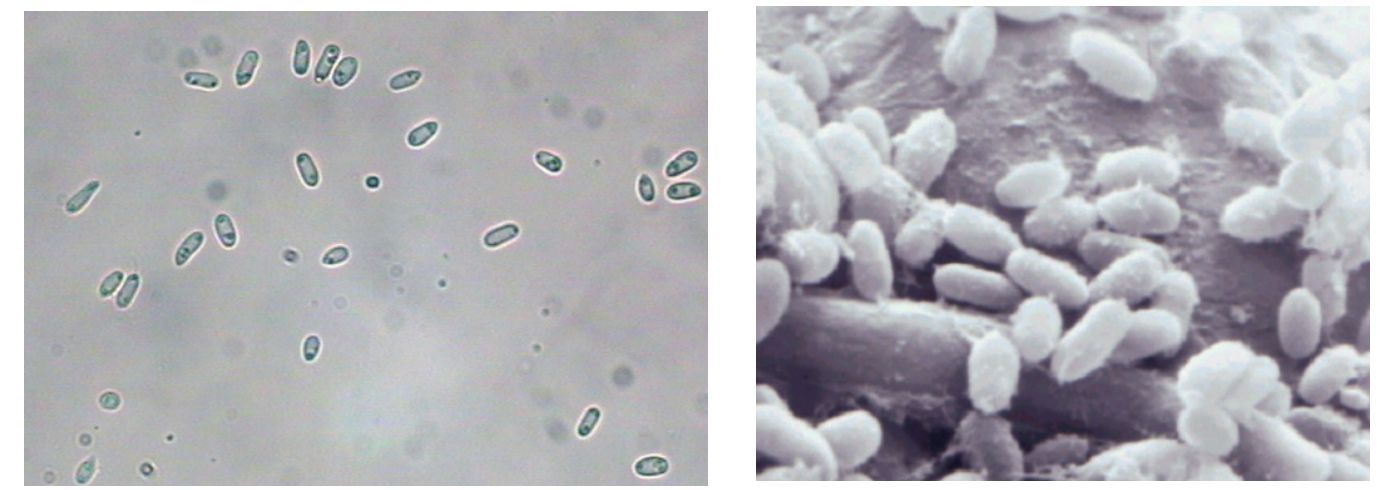

b

Fig. 2. Conidia Phoma exigua var. exigua - x 500 (a) - photo E. Zalewska; SEM - x 6700 (b) - photo M. Wróbel; on malt - agar.
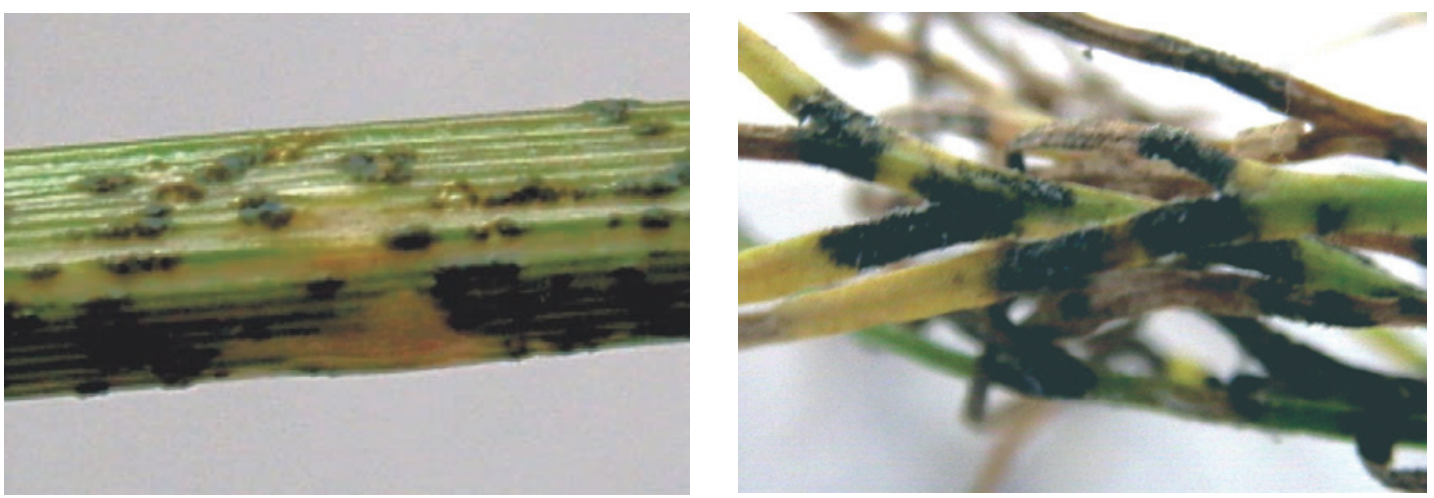

Fig. 3. Necrosis on stem and leaves of dill naturally infected by Phoma exigua var. exigua-photo E. Zalewska.

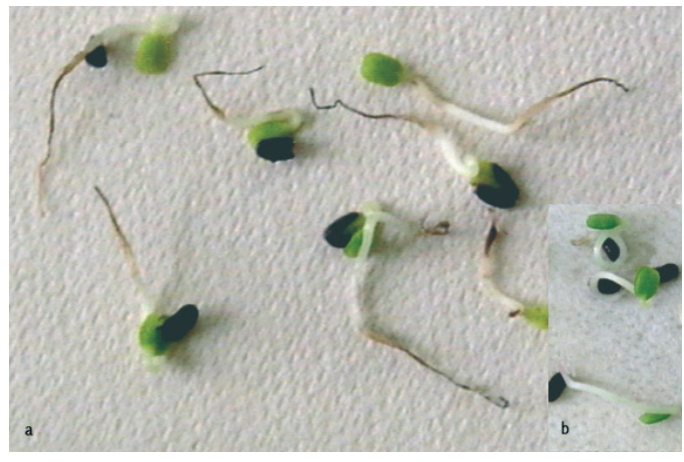

Fig. 4. Effect of inoculation of thyme shizocarps with water suspension of conidia Phoma exigua var. exigua (a), control (b) - photo E. Zalewska.

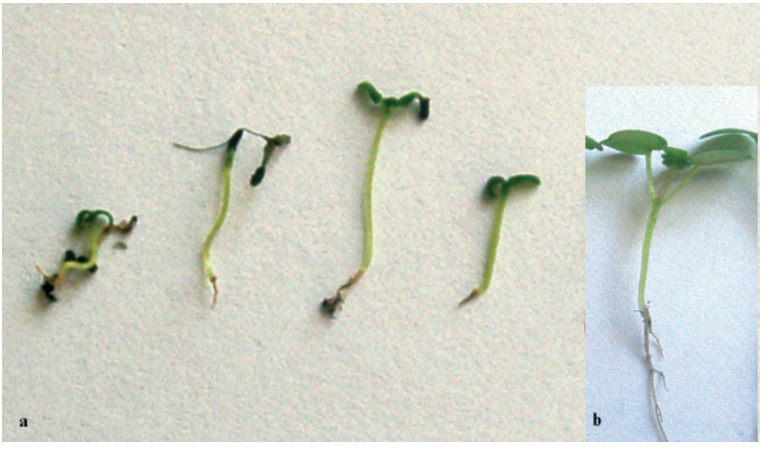

Fig. 5. Seedlings of thyme from pots with soil infected with Phoma exigua var. exigua (a), control seedlings (b) - photo B. Zimowska. 
P. exigua var. exigua, with the macroscopic and microscopic features corresponding to those of the cultures used for artificial infection, was isolated from the decayed germs and shizocarps that did not germinate. The largest number of $P$. exigua var. exigua cultures were reisolated after using isolates T 299 and T 277 (Tabs 2, 3).

In the contact with the water suspension of P. exigua var. exigua, from 66 to $70 \%$ shizocarps of lemon balm did not germinate till the $9^{\text {th }}$ day of observation (Tab. 2). The mean number of the shizocarps that did not germinate, which ranged from 13.2 to 14 , was significantly higher than in the control combination (Tab. 3). The number of the germinated shizocarps of lemon balm after 9 days ranged from 30 to 34 (Tab. 2). However, more than half of the germs showed the signs of strong necrosis, leading to their decay (Tab. 2 ). The mean number of germs with necrosis that had contact with the fungus was - independently of the isolate - significantly higher than in the control (Tab. 3). Like in the case of garden thyme, necrosis of the germs was visible in the form of light brown spots graduating into longitudal streaks. The germs were very thin and inhibited in growth. Like in the case of garden thyme, $P$. exigua var. exigua cultures were isolated from the non-germinating shizocarps of lemon balm and from the germs with the signs of necrosis. Their macroscopic features corresponded to the features of the cultures used for artificial infection. The number of $P$. exigua var. exigua cultures reisolated from lemon balm was the highest as a result of using the isolates M 1657 and M 1635 for inoculation, and it was 43 and 39, respectively, while the mean number of $P$. exigua var. exigua cultures reisolated from the shizocarps of lemon balm after using those isolates was 14 and 7.8, respectively (Tabs 2, 3).

An average of 3.6 of plants emerged as a result of artificial infection of thyme shizocarps with the isolate T 299 of P. exigua var. exigua through the infected soil. That value was significantly lower than in the control combination (Tab. 4). Within this number, 3.1 were the seedlings with necrosis of the germs and the hypocotyl, and that value was significantly higher compared to the control combination (Tab. 4). Cultures of the fungus $P$. exigua var. exigua used for artificial infection were reisolated from the infected seedlings of thyme. On the other hand, this species was not isolated from the control plants (Tab. 4). The seedlings obtained in the experimental conditions were - contrary to the control plants - inhibited in their growth, they had small cotyledons and decayed endings of the roots (Fig. 5). These seedlings died out within 3-4 days.

An average of 5.9 of plants emerged as a result of inoculation of lemon balm shizocarps with the isolate $\mathrm{M}$ 1657 of $P$. exigua var. exigua through the infected soil. That value was significantly lower than the value in the control combination (Tab. 4). The mean number of seedlings with necrosis of the seedlings and the hypocotyl was 4.1, and it was significantly larger than in the control combination (Tab. 4). The mean number of $P$. exigua var. exigua cultures reisolated from the infected seedlings of lemon balm was 4.4 (Tab. 4). The fungus was not isolated from the control plants. The lemon balm seedlings in the experiment with artificial infection with the isolate M 1657 of $P$. exigua var. exigua, in comparison to the seedlings in the control combination, were inhibited in their growth and had a reduced root system and necrosis of the root endings.

\section{DISCUSSION}

The character of the growth of the colonies of the studied fungus isolates, the morphology of the pycnidia and conidia as well as physiological-biochemical properties, corresponding to the description of the monograph of Phyllostictoides section (B o e r e m a et al. 2004), were decisive in the identification of the studied isolates into the species of $P$. exigua var. exigua. The reaction of those isolates with $1 \mathrm{~N} \mathrm{NaOH}$ proved to be variable, depending on the subsoil and the isolate, which is consistent with the information of other authors on the difference in the strength of the reaction of $P$. exigua var. exigua isolates with $\mathrm{NaOH}$ (B o e r e ma et al. 2004). Due to the occurrence of $P$. exigua var. exigua on plants in a complex with other fungi species, including those producing pycnidia, it is not easy to find out its presence. Besides studying the microscopic elements of the fungus developing on plants, it is necessary to isolate it onto an artificial medium and to identify it on the basis of the properties on standard media (de Gruyter and Noordelos s, 1992; de Gruyter et al. 2002).

The obtained results confirm the fully polyphagous nature of $P$. exigua var. exigua. The familiar numerous species of host plants to the fungus (Marcink ow k k a, 1985; F a r r et al. 1995; B oe re m a et al. 2004) should include the species studied in the present paper. Among them, plants from the genera Leonurus, Melissa and Mentha were mentioned in other authors' papers (F a r r et al. 1995) as hosts to $P$. exigua var. exigua. The present paper and papers from recent years ( $\mathrm{M}$ a c h ow i c z-S te fan iak and Zimowska 2000; Machowicz-Stefaniak et al. 2002 a; 2002 b; Zimowska and Machowicz-Stefaniak, 2004) provide information on the occurrence of $P$. exigua var. exigua on other studied herb species. The ability of the fungus to colonize the aboveground and underground parts of herbaceous plants and the facultative character of its parasitism, which was shown in the present studies, point to the 
fact that $P$. exigua var. exigua easily survives in unfavourable conditions. It can survive on the surface of the sowing material or inside seeds, which was shown in the case of Achillea millefolium, Coriandrum sativum, Carum carvi, Anethum graveolens, Thymus vulgaris and Pastinaca sativa as well as on the after-crop residue of infected plants or roots and lower parts of stems of perennial herb species. The frequent colonization of herbaceous plants by $P$. exigua var. exigua in natural conditions and positive results of the pathogenicity tests confirmed by the fungus reisolation point out that the studied isolates can be considered as accidental pathogens of thyme and lemon balm. Their harmfulness consists in inhibiting the germination of shizocarps and emergences of the tested herb species, in causing necrosis of seedlings, roots and hypocotyls of seedlings. Causing necrosis of infected organs is certainly related to the production of the enzyme of $\beta$-glucosidase by the fungus ( $\mathrm{G}$ i e b e 1 and $\mathrm{D}$ o p i e r a ła, 2004). High biological activity of $\beta$-glucosidase was shown in $P$. strasseri, a dangerous pathogen to pepper mint (G i e b e 1 and D o p i e rała, 2004; Z i m o w s $\mathrm{ka}$ and Machowicz-Stefaniak, 2005). Likewise, potato gangrene is a consequence of $P$. exigua var. foveata exudating a complex of enzymes, including $\alpha$ - and $\beta$ - glucosidase and $\alpha$-galactosidase ( $\mathrm{B}$ o e $\mathrm{r}$ e $\mathrm{m}$ a et al. 2004; G i e b e 1 and D o p i e r a ła , 2004). The applied methods of inoculation proved useful in testing $P$. exigua var. exigua pathogenicity towards herbaceous plants as they ensured a direct contact of the fungus with shizocarps, seedlings and seedling roots. The method of soaking the sowing material in a water suspension of the germs, also positively estimated in reference to soybean seeds, proved effective and useful in evaluating the pathogenicity of numerous isolates of the fungus ( $\mathrm{Marcink} \mathrm{ow} \mathrm{k} \mathrm{a,1984).}$ The lack of a significant difference in the harmfulness of $P$. exigua var. exigua isolates originally obtained from thyme towards this plant and the harmfulness of isolates obtained from lemon balm towards the latter seems to confirm earlier suggestions on the relationship between the pathogenicity of fungi and the origin of the isolates ( $\mathrm{Ka} \mathrm{c} \mathrm{i} \mathrm{c} \mathrm{o} \mathrm{w} \mathrm{a} \mathrm{et} \mathrm{al.} \mathrm{1992;} \mathrm{Z} \mathrm{a} \mathrm{l} \mathrm{e} \mathrm{w} \mathrm{s} \mathrm{k} \mathrm{a}$ and $\mathrm{Machow}$ ic z-S tefaniak, 2004).

\section{REFERENCES}

Boerema G. H., 1976. The Phoma species studied in culture by Dr R. W. G. Dennis, Trans. Br. Mycol. Soc. 67: 28.

Boerema G. H., Höweler L. H., 1967. Phoma exigua Desm. and its varieties. Persoonia, 5: 15-28.

Boerema G. H., Gruyter J.de, Noordeloos M.E., Hamers M.E.C., 2004. Phoma identification manual. Differentiation of specific and infra-specific taxa in culture. CABI Publising: 470.
Gruyter J. de, Noordeloos M. E., 1992. Contributions towards a monograph of Phoma (Coelomycetes) - I. 1. Section Phoma: Taxa with very small conidia in vitro. Persoonia, 15: 71-92.

Gruyter J. de, Boerema G. H., Aa H. A. van der, 2002. Contributions towards a monograph of Phoma (Coelomycetes) VI-2. Section Phyllostictoides: Outline of its taxa. Persoonia, 18 (1): 1-53.

Farr D. F., Bills G. F., Chamuris G. P., Rossman A. Y., 1995. Fungi on plants and plant products in the United States. The American Phytopathological Society, St. Paul, Minesota USA.

Giebel J., Dopierała U., 2004. Pathogenesis of potato gangrene caused by Phoma exigua var. foveata: II. Activities of some hydrolases and dehydrogenases. J. Phytopathol. 152 (7): 399-403.

Łacicowa B., 1964. Badania mikroflory materiału siewnego pszenicy uprawianej na obszarze woj. lubelskiego, uwzględniające szczególnie grzyby patogeniczne. / A study on the microflora of seed material of wheat grown in the Lubelskie Voivodship (region) area, with special attention to pathogenic fungi. Ann. Univ. Mariae Curie-Skłodowska sect. E, 19: 381-406.

Łacicowa B., Kiecana I., Pięta D., 1992. Mikroflora nasion Bellis perennis i Celosia cristata. / Microflora of Bellis perennis and Celosia cristata seeds. Acta Mycol. 27 (1): 41-48.

Machowicz-Stefaniak Z., Zalewska E., 2004. Patogeniczność grzybów z rodzaju Fusarium dla tymianku właściwego (Thymus vulgaris L.) uprawianego na Lubelszczyźnie. / Pathogenicity of fungi of the genus $\mathrm{Fu}$ sarium towards thyme (Thymus vulgaris L.) grown in the Lublin region. Acta Sci. Pol. Hortorum Cultus, 3 (1): 115-123.

Machowicz-Stefaniak Z., Zimowska B., 2000. Grzyby przenoszone przez materiał siewny roślin zielarskich. / Fungi transmitted by seed material of herbaceous plants. Acta Agrobot. 53 (2): 25-38.

Machowicz-Stefaniak Z., Zalewska E., Zimowska B., 2002 a. Fungi colonizing various organs of lemon balm (Melissa officinalis L.) cultivated in South-East Poland. Proc. $6^{\text {th }}$ Conf. EFPP 2002, Prague. Plant Protection Sci. 38 (Special Issue 2): 353-356.

Machowicz-Stefaniak Z., Zimowska B., Zalewska E., 2002 b. Grzyby zasiedlające różne organy tymianku właściwego (Thymus vulgaris L.) uprawianego na Lubelszczyźnie. / Fungi colonizing various organs of thyme (Thymus vulgaris L.) cultivated in the Lublin region. Acta Agrobot. 55 (1): 158-197.

Marcinkowska J., 1984. Methods of estimation of the pathogenicity of fungus Phoma exigua var. exigua. Acta Agrobot. 37 (2): 141-155.

Marcinkowska J., 1985. Charakterystyka izolatów Phoma exigua. Acta Mycol. 21 (1): 81-90.

Zalewska E., Machowicz-Stefaniak Z., 2004. Patogeniczność grzybów z rodzaju Fusarium dla melisy lekarskiej (Melissa officinalis L.). / Pathogenicity of fungi 
of the genus Fusarium towards lemon balm (Melissa officinalis L.). Acta Sci. Pol., Hortorum Cultus, 3 (2): 33-39.

Zimowska B., Machowicz-Stefaniak Z., 2004. Grzyby zagrażające uprawie dziurawca zwyczajnego (Hypericum perforatum L.) w województwie lubelskim. / Fungi threatening the cultivation of St. John's wort (Hypericum perforatum L.) in the Lubelskie Voivodship (region). Acta Sci. Pol., Hortorum Cultus, 3 (1): 61-74.

Zimowska B., Machowicz-Stefaniak Z., 2005. Charakterystyka izolatów Phoma strasseri nie notowanego w Polsce patogenu mięty pieprzowej (Mentha piperita L.). / Characteristics of isolates of Phoma strasseri, a pathogen of peppermint (Mentha piperita L.). not noted in Poland. Acta Agrobot. 58 (2): 151-162.

\section{Występowanie i patogeniczność Phoma exigua Desm. var. exigua dla wybranych gatunków ziół}

\section{Streszczenie}

Phoma exigua var. exigua izolowano w latach 1998-2006 z nadziemnych i podziemnych organów różnych gatunków ziół. Przeprowadzono testy patogeniczności trzech losowo wybranych izolatów grzyba T 299, T 261 i T 277 dla tymianku właściwego oraz trzech izolatów M 1657, M 1193 i M 1635 dla melisy lekarskiej. Określano oddziaływanie wodnej zawiesiny zarodników grzyba na zdolność kiełkowania rozłupek oraz sztucznie zakażonej ziemi na wschody i zdrowotność siewek. Dla identyfikacji P. exigua var. exigua niezbędne są badania mikroskopowych elementów grzyba rozwijających się na roślinach, izolacja grzyba na sztuczne podłoże oraz analiza cech makro i mikroskopowych na podłożach standardowych. Uzyskane wyniki potwierdzają polifagiczny charakter grzyba. Testowane izolaty uznano za okolicznościowe patogeny tymianku właściwego i melisy lekarskiej w badanych warunkach. Ich szkodliwość polega na hamowaniu kiełkowania rozłupek oraz wschodów roślin, zdolności do wywoływania nekrozy kiełków, korzeni i podliścieniowej części siewek. 